\title{
The impact of quality leader member exchange on job satisfaction Mediating effect of organizational commitment
}

\begin{abstract}
Purpose: The main objective of this study is to examine the influence of quality member exchange (LMX) on the Job Satisfaction of employees working in the commercial banks of Sindh with the mediation role of Organizational Commitment.

Design/methodology/approach: The data was collected through questionnaires which consist on 5 point likert scale measuring LMX, JS, and OC. Total respondent were 226 employees ranked as managers and operation managers from more than 120 branches of commercial banks of Sindh. The testing of hypotheses was done through confirmatory factor analysis as well as structural equation model.

Findings: The results of the paper indicate that Organizational Commitment acts as a full mediator between: leader member exchange and Job Satisfaction. Results also highlight, Leader member exchange has significant influence on Job Satisfaction and all constructs are positively correlated.

Originality/value: This area of study adds in literature of organizational behavior. It investigates the relation-ship between antecedents (LMX and JS) and result (OC) which act as to mediator and its effect of antecedents on relationship between LMX and JS through an integrated structural model. On the basis of the findings, this study advocates the theoretical as well as managerial implications.
\end{abstract}

Keywords: leader member exchange, job satisfaction, organizational commitment
Volume 3 Issue 5 - 2019

\author{
Ghulam Mustafa Shaikh,' Jalil Ahmed Thebo, ${ }^{2}$ \\ Mehwish Jamali, ${ }^{3}$ Fareeda Sangi, ${ }^{4}$ Sartaj \\ Ahmed Sangi, ${ }^{4}$ Ghulam Murtaza Sheikh ${ }^{5}$ \\ 'Assistant Professor, Head of Business Department, Sindh \\ University Campus, Larkana, Pakistan \\ ${ }^{2}$ Faculty Member, SZABIST Larkana Campus, Pakistan \\ ${ }^{3}$ Faculty Member, Department of Business Administration, \\ Shaheed Benazir Bhutto University, Pakistan \\ ${ }^{4}$ Faculty Members, Department of Business Administration, \\ Sindh University Campus, Larkana, Pakistan \\ ${ }^{5}$ Lecture, Govt. Arts and Commerce College, Pakistan
}

Correspondence: Ghulam Mustafa Shaikh,Assistant Professor, Head of Business Department, Sindh University Campus, Larkana and Ph.D. Scholar Shah Abdul Latif University Khairpur, Pakistan, Tel +92 332 2773262, ORCID: 0000-0002-8229-5249, Email gm.shaikh@usindh.edu.pk

Received: August 07, 2019 | Published: October 29, 2019

\section{Introduction}

Commercial Banks have a keen interest to boost their organizational performance which directly affects their profitability. In previous three decades, commercial banks have realized great relationship of organizational behavior with profitability. Profitability of banks has many aspects such as financial stability, organizational efficiency and employees' work behavior. Employees are an integral part of any organization's success and are a point of differentiation. ${ }^{1}$ In Pakistan, the rising competition in commercial banks has led to the concern of human resource and employees' performance which is based on many factors such as the LMX (leader member exchange), OC (organizational commitment) and other outcomes. The Commitment is determined by the quality of leader member exchange which is an important aspect of overall success of organization's growth. ${ }^{2}$

The Commercial banks must develop strategies to overcome the challenge of rising competition in the banking industry. To accomplish this goal, the banks need employees that are committed to their organization, aggressive, unique in skills and honest. ${ }^{3}$ Commercial banks need employees that can go beyond their formal job description and can exhibit high levels of commitment to their banks to sustain competitive advantage. Considering the higher costs of recruiting new people, Commercial banks have to rethink about the traditional staffing methods and try to increase the retention of employees in the organization and commitment. ${ }^{4}$

There is theoretical relationship to evidence that supports the relationship in between both Leader Member Exchange and
Organizational Commitment. Both are positively correlated. ${ }^{5}$ In response to the theory and literature support, Leader Member Exchange impacts Organizational Commitment. This research aims to evaluate the impact of LMX on OC in the Managers of Commercial banks of Sindh.

The competition in the commercial banks is rising with the time, to sustain competitive advantage the organizations behavior is to be understood. The Employees are an important part of organizational behavior. Employee's organization commitment is a crucial aspect of organization's productivity; therefore, it is desired for employees to have rich and healthy relationships amongst them to exhibit higher levels of commitment. The quality of relationship among subordinate and his leader decides the OC of employees in an organization. This study aims to assess the impact of quality of LMX on organizational commitment of employees in commercial banks of Sindh.

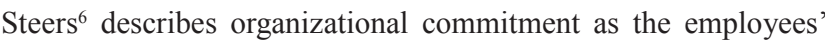
evaluation of positivity towards the entity and organizational goals. The strength of bond between an individual and Organization is called Organizational Commitment. ${ }^{7}$ Mowday et al..$^{8}$ called this theory as Vertical Dyad Linkage theory but later was called as the termed LMX. ${ }^{9}$ This LMX theory emphases on the conflicting relationships that supervisors develop with secondary people in a work setting. ${ }^{10}$ Liden et al. ${ }^{11}$ has derived that LMX is correlated positively to OC and Job Satisfaction. Deluga ${ }^{12}$ have found that there is organizational commitment is directly affected from Leader Member Exchange. Yukl $\mathrm{G}^{13}$ have also found the same positive relation-ship between LMX with Organizational Commitment. 


\section{Significance of the Study}

The Human Resource departments of banks have faced a great problem of conflict of employees among themselves and with their leaders. The LMX is as important for commercial banks as any other organization. There are many factors that trigger productivity and profitability of Commercial Banks, one of the most prominent factor is the relationship between the supervisor (Boss) and the Employee i.e. Leader Member Exchange. If the Quality of LMX is high, employees are expected to be overall satisfied resulting in higher productivity and Profitability of banks and if the quality of LMX is low, the employees are expected to be overall dissatisfied resulting in low productivity and Profitability of banks.

In Today`s era of Information Technology and Knowledge, it is very important for commercial banks to taken into consideration important aspects like Leader Member Exchange which have direct impact on work outcomes (as referred by literature). Since very little and insufficient work has been done on Leader Member Exchange in Commercial banks this research contributes to better determination of impact of Leader Member Exchange on commercial of banks.

This study will be useful for commercial banks in understanding the importance of quality of LMX and its impact on organizational commitment. This can be used by commercial banks to enable them to achieve higher efficiency by eliminating the obstacles and boosting higher degree of commitment through high quality leader member exchange. This study can be used as an important tool in developing HR strategies leading to achievement of corporate goals.

\section{Literature review}

\section{Leader member exchange}

LMX is said to be an exchange process between a leader and a follower which is dependent upon the interpersonal skills, traits, trust, support, rewards and satisfaction with the leader; furthermore, LMX could be defined as an exchange process and as leader's approval. ${ }^{10} \mathrm{LMX}$ also highlights to a work-related exchange relationship between subordinates and their respective immediate supervisor. Different quality of exchange relation-ship with each of his/her subordinate are developed by a supervisor. The LMX quality is based on mutual trust, liking and respect. ${ }^{13}$

\section{The origin of leader member exchange}

The study of the leader and follower is as old as time, it has his inception from the vertical dyad linkage model. ${ }^{14}$ Now, It has changed into LMX theory of the current era, In the early years of the examination, the main concern was to further improve the theory development of LMX. ${ }^{15}$ after all this the social exchange theory became more persuasive. Early LMX work was more related towards the development of the theory, associates, and results of LMX were explored. ${ }^{16}$ Later on, the researchers have started to address LMX demarcation. ${ }^{17}$ The absence of guide devotee understanding in LMX appraisals Cogliser et al. ${ }^{18}$ and the multi-leveled nature of LMX (i.e., distinguishing that people are secondarily settled in dyads, in aggregations, and in associations)

\section{LMX Theory}

LMX was initially regarded as a vertical-dyad linkage theory, and was firstly reported by Dansereau, and Graen. ${ }^{14}$ Different from the all previous theories which stated that leader treat all of his followers in an equal manner, LMX was totally opposite to them, and it asserted that leader has a different way of treating to all the followers. ${ }^{10}$ LMX is more inclined towards the exchange relation-ship between a follower and a leader \& the quality of the exchange process which is between the both. So the main area of the interest in this theory is the dyadic relation-ship between the leader and his subordinates. ${ }^{19}$

\section{Types of LMX}

LMX utilizes exchange theory to depict the connection that occurs among leaders and followers. Two main kinds of exchange have been distinguished and named. ${ }^{14}$ Poor LMX or (distant group) and an excellent LMX regarded as a (close group relationship). The former can be described as a relation-ship that is limited among the leader and a follower and the basis of this relation is the formal authority between and the contract between them and the job description of the employees which he follows .9

\section{High quality LMX}

Graen \& Scandura ${ }^{10}$ have proposed that The Employees In high quality relation-ships obtain more benefits as related to those employees in low quality relationship. The advantages include enhanced contact, enhanced functions; higher stages of perceived support in emotional sense and high level of contact with leaders. Wayne et al. ${ }^{20}$ state that in these groups have exceptional relationships with an internal circle of assistants and advisors, who frequently get high levels of responsibility and access to resources.

\section{Low quality LMX}

Gerstner \& Day ${ }^{16}$ believe that the exchange of employees in lower-quality LMX are extra prone to ordinary tasks to execute, get less support of supervisor and have more negative feelings about the organization and workplace. They tend to have higher degree of turnover intentions. Low Quality LMX forms group, also known as the "out-group," and they distinctively prove to be less motivated or less capable in contrast to the other group. In-group employees are more determined to put in intense efforts, is more dedicated to task objectives, and split more administrative duties.

\section{Dimensions of LMX}

Liden et. al. ${ }^{11}$ have developed a multidimensional model of LMX , four dimension model of Leader Member Exchange rather than one dimension model and it explains the concept of leader member exchange more accurately and completely. There are four dimensions The Interpersonal relationships such as friendship without inclusion of work or professional relationship is called Affect. It is the mutual affection within the supervisor and subordinates relationship. Loyalty is explained by the extent of support each member gives to others and its leader for the fulfillment and accomplishment of others personal goals. Contribution is the amount of effort each member puts in work to accomplish goals, the extent of work activity shared by each member. Professional Respect is the reputable relationship each member-leader has made within them within or externally related to his/her work.

\section{LMX and work outcomes}

The research on the relation-ship between LMX quality and work outcome has been uncertain. From one viewpoint, the primary impacts of LMX quality on the work conclusions of organizational citizenship behaviors $^{21}$ and work performance, ${ }^{22}$ organizational responsibility and turnover Intentions were discovered. LMX alludes to a work-identified trade relation-ship between subordinates 
and their respective quick chief. A boss advances an alternate nature of trade association with each of his or her subordinates in the same work bunch. ${ }^{19}$ The nature of LMX is dependent upon shared trust, appreciation, and enjoying. ${ }^{13}$

\section{Job Satisfaction}

Job satisfaction as the extent to which people are satisfied with their work or define show they feel about various aspects of their work. Job satisfaction adds the level of employment, seniority, salary, employee empower mental and skill variety and type of skills

\section{History and philosophy of job satisfaction}

The job satisfaction is the early 1900's concept that was focused from that time. At the time of 1900's job satisfaction was determined by the few characteristics of the job and its environment. The very old researchers Cranny et al. ${ }^{23}$ gave the brief studies. This study was done on the western Electric Plants. Hawthorne studies give the assumption that when the some job conditions that are followed are present in a level of job satisfaction. A Hawthorne study is as an experimental effect where the people's behavior is under observation and being watched how they act at the workplace. At that early stage of Hawthorne, the Hawthorne studies gave the birth to job satisfaction research.

\section{Dimensions of job satisfaction}

1. Work Itself is a factor by which job satisfaction is influenced in an organization. In 1992 Luthan $^{24}$ identified that employees get satisfaction from the most challenging and interesting work and they like that job which provides them a good level of status.

2. Pay is the important factor for job satisfaction because if a person is doing job it is because of fulfilling his monetary needs. According to luthans ${ }^{24}$ pay only helps the person to fulfill their basic and upper level needs of satisfaction. Pay is a financial advantage that an employee receives for the work done. Pay is complex factor in job satisfaction. Many of the researchers have found that employees work in the organization for satisfying their basic needs through getting pay.

3. Supervisory behavior plays an important role with employees reactions. Employees want a type of bonding relation with their supervisor who trusts them. It reflects that if supervisors support the individuals in accomplishing the tasks so the individuals are satisfied with their jobs. ${ }^{25}$

4. Promotions: Favorable circumstances and the advancement opportunities in the job level also satisfy an employee, those favorable circumstances are termed as promotions. Employees expect the future opportunities at the fair level. Whereas all the employees are not promoted because promotion is given to that person who handles higher level of responsibility and their targets are more complex and difficult.

5. Co-Workers: Social relations in workplace will satisfy the employee and he will be more committed to the organization. According to Mowday, ${ }^{8}$ the interactions between the co-workers also influence the job satisfaction. This reflects that if there are good relationships between the employees so the satisfaction level is higher. The social relationships at the organizations create the social climatic conditions. These relationships give an identity to the employee in a personal way.

6. Working Conditions: Job satisfaction is also influenced by the environment of the organization. According to Luthans, ${ }^{24}$-if people work in a clean, friendly environment, they will find it easier to come to work. But if the environment is polluted and job is at a very posh area so the level of job satisfaction decreases as well as the organization's performance declines.

\section{LMX and job satisfaction}

Job Satisfaction has been characterized as a "pleasurable or positive enthusiastic state coming about because of the evaluation of one's employment or work encounters". Expanding this definition, later conjecturing ${ }^{26}$ depicts work fulfillment as a disposition ${ }^{27}$ with both an emotional segment (inclination, feelings) and a cognitive part (conviction, judgment, comparison).

Gerstner and Day ${ }^{16}$ directed a meta-dissection of 25 years of observational research on LMX hypothesis in which they assessed relationships between LMX and connects and in addition LMX develop and guide part agreement. Full of feeling responsibility alludes to the degree to which representatives relate to, are included in, and are passionately connected to an association so they need to stay in it. ${ }^{28}$ Consistent with LMX hypothesis ${ }^{19}$ due to the broadened assets and solid underpin accessible to an adherent in a superb LMX relationship, such a relationship can bring about additional inspirational state of mind at the employment and the association and in addition higher work execution for the supporter. Indeed, Gerstner and Day ${ }^{16}$ discovered solid back for positive connections between LMX and in general work fulfillment organizational responsibility and work performance.

\section{Organizational commitment}

In the organization the engagement and connection refer to worker's emotional attachment and recognition. In essence, Worker his own principles and attitude and those employees of the organization evaluating organization commitment is a review of the similarity. ${ }^{29}$ Employee's motivation and added value to the organizational goal is organizational commitment. When employees come to know that they can rise and trained with existing organization, there is more continuation of commitment standard with that particular employer. ${ }^{30}$

The organizational commitment and Job Satisfaction are highly correlated and Job Satisfaction depends on how good is organization in understanding the expectation of workers. Contrary to this Steele and Maxwell ${ }^{31}$ understood that the concern of organization is dependent on the concern of employees, while it is oblivious that more experience results in higher impact on commitment. With co-workers the experience of the individuals had relationship on commitment to the organization in higher degree. Commitment itself leads to good and positive high standard of work routine and give clear hub to human resource managers. Tella et al. ${ }^{32}$ telling organizational commitment has powerful authority on people's intentions, also act upon the motivation, making high skills of his or her is increases effectiveness. Turnover, non-attendance, output and organizational goals should be forecast in organizations with organizational commitments.

\section{Three factors of organizational commitment}

\section{Affective commitment}

According to Meyer and Allen's ${ }^{28}$ view, the attachment and recognition within the organization which raises emotional alliance is called affective commitment. The personal preference to stay in an organization due to any factor such as good salary, better supervisors, role and status, such preference of an organization is called Affective commitment. The existence of similar values of organization and the employee gives a sense of positive integration. ${ }^{33}$ 


\section{Continuance commitment}

Continuance commitment is referred as the type of commitment arising out of the perceived costs and other costs in switching the organization. Demographic variables such as age, qualifications and the length of service in an organization are the determinants of continuance commitment. ${ }^{34}$ These demographic variables have moderating effect on continuance commitment. The compulsion of employee to stay in an organization is termed as normative commitment, thus employees share a common belief that staying in the organization is the correct and legitimate thing to do. The level of assertive social experience of an employee with an organization has, it impacts the stay of employees in an organization. ${ }^{20}$ The benefits that an employee enjoys create an internal feeling to respond with the same justified morale to the organization, such feeling of commitment is called continuance commitment. ${ }^{36}$. Murray et al. ${ }^{37}$ explains It is also considered that employees are committed to their work because of perceived risks that they will not get the same level of benefits anywhere else or cannot find another job. At that point, Continuance commitment is identified with one's experience and what one has provided for an association.

\section{Normative commitment}

Normative commitment refers to the employees feeling of a sense of responsibility towards the organization; they feel that the commitment is the correct and legitimate. ${ }^{35}$ Employees usually try to compensate organization for the extra ordinary benefits that they enjoy by staying committed to their organization; such commitment is called normative commitment. ${ }^{38}$ In addition, Meyer et al. ${ }^{38}$ proposes that the educational and skillful set that a person learns at a particular organization is not easy to be transferred, therefore it is difficult to switch organizations and the commitment in entailed.

\section{Leader member exchange and organizational commitment}

The research by Needle David ${ }^{39}$ states that LMX theory suggests a central idea that relationships of different types are developed by supervisors with their subordinates within an organization. These relationships possess qualities which determine efforts; both physical and mental, information, material resources and social support, as swapped between subordinate and supervisor. Therefore, LMX which possesses high quality relationship engage a worthy swap of effort, support and resources in between the two individuals while LMX of low quality engages in a very minor swap, support between two individuals.

Research on In groups and out groups by Chen et al., ${ }^{40}$ drawn conclusion that strong commitment, better satisfaction and high level of performance can be observed by those members that are "in group" while weak commitment, lower satisfaction and performance is observed by members that are "out group". While the scholarly work by Angle et al. ${ }^{41}$ which has been done in the recent years has shown consistently identified that the leader member exchange has direct impact over the organization commitment.

\section{Theoretical framework and hypothesis}

H1: Leader member exchange, Job Satisfaction and organizational Commitment are positively correlated with one another.

H2: Leader member exchange is related positively to Organizational Commitment.

H3: Organizational Commitment is related positively to Job Satisfaction.
H4: Organizational Commitment acts as a mediator between Leader member exchange and Job

Satisfaction.

\section{Research methodology}

\section{Research design}

This research is Quantitative and Causal in nature. The survey method has been employed to collect the data. The survey focused on commercial banks, Private and Public, of selected Districts of Sindh province such as Karachi, Hyderabad, Sukkur, Larkana, Dadu, Khairpur, Shikarpur, Jacobabad \& Nawabshah. Only Middle, Operational and Front Line level managers having two years' experience were considered to be a part of this study.

The approximately population was 1662 . The managers from Islamic Banks and Microfinance banks were not part of this study. The Stratified sampling Technique was used. The 600 questionnaires were distributed among the selected branches in different commercial banks of the different districts, only 252 filled questionnaires were received whereas 26 among them were discarded due to missing/ incomplete sections.

\section{Instrument/Measures}

\section{Leader member exchange}

LMX, OC and JS were measured through Scandura, ${ }^{42}$ Mowday et al. ${ }^{8}$ consisting of $11,13 \& 07$ items respectively under 5 points likert scale, where 1 represents "Not at all" and 5 represents "To Great Extent".

\section{Demographics}

The Questionnaire was also contained four other demographic variables such as age, gender, experience and education.

\section{Data analysis}

The data in this study was analyzed by Statistical Packages for Social Sciences (SPSS-18) and Analysis of Moments of Structure (AMOS-18). In the first step, the collected data was screened; missing values, descriptive statistics, normality, detection of multivariate outliers were detected. The confirmatory factor analysis was run before conducting the structural equation modeling (SEM).

The fitness of the model comprising of Goodness-of-fit (GFI), Comparative fit index (CFI), Normed fit index (NFI), Adjusted goodness-of-fit index (AGFI) \& root mean square error of approximation (RMSEA) measures were taken in this study. The acceptable criteria for the fitness of the model can be less than 0.9 for GFI, AGFI and NFI ${ }^{43}$ CFI statistics can be below 0.95 . Whereas the value of RMSEA below 0.05 shows an outstanding model fit. ${ }^{44}$ Additionally, the acceptable values which signify the satisfying fit are lower than 0.06 and 0.09 .

\section{Results}

\section{Respondent's profile}

The Table 1 shows the statistics and percentages of male and female among the respondents, the results revealed that the number of males was $201(89 \%)$ and female was $25(11 \%)$ among total 226 respondents. Whereas $127(56.5 \%)$ of respondents fall into the age group of 21-30 Years, 66 (29\%) of respondents fall into the age group of 31-40 Years and $33(14.5 \%)$ of respondents fall into the age group of 41 or above. The results revealed that the highest percentage of 
respondents fall into the category of 20-30 year of age. In connection with education of the respondents the obtained results exposed that $21 \%$ of respondents have completed their bachelors while $79 \%$ of respondents completed their Masters Education. This shows that the majority of respondents have completed their master's education. $77(33.9 \%)$ of respondents have experience between 2-3 years, 58 (25.8\%) of respondents have experience between 3-6 Years whereas $91(40.3 \%)$ of respondents were experienced of more than 6 years. The result reveals that majority of the respondents have experience of more than 6 years.

Table I Respondent's profile

\begin{tabular}{llll}
\hline Employee details n=226 & Frequency (s) & Percentage \% \\
\hline Male & 201 & 89 \\
Female & 25 & 11 \\
Total & 226 & 100 \\
Age(in years) & & 127 & 56.5 \\
2I-30 & & 66 & 29 \\
3I-40 & & 14.5 \\
4I-onwards & & \\
Qualification & 47 & & 21 \\
Bachelors & 179 & 79 \\
Masters & & \\
Experience (in years) & 77 & & 33.9 \\
Min. 02 years & 58 & 25.8 \\
03-06 years & 91 & 40.3 \\
More than 06 Years & & & \\
\hline
\end{tabular}

\section{Overall reliability of constructs}

Hair et al. 2007 defines reliability that the level to which the variable or set of variables are matched with that is intention to measure. Fujun et al. 2007 mentioned that the Cronbach's Alpha with acceptable cut off point 0.70 expresses that all the variables are internally in consistent. The Table 2, portrays the reliability of the overall scale used in this research is .904 representing $90.4 \%$ reliability of scale consists of 31 items confirming the internal consistency of constructs. The Table 2 individually shows that the reliability of the 11 items of leader member exchange (independent variable) is 0.845 representing $84.5 \%$ reliability, the reliability of the 13 items of organizational commitment (mediating variable) is $0.883(83.3 \%)$ and $0.912(91.2 \%)$ of Job Satisfaction (Dependent Variable) representing of 07 items confirming the internal consistency of variables. The Average Variance Shared (AVE) of all constructs is more than $50 \%$ whereas the statistics of Maximum Shared Variance (MSV) and Average Shared Variance (ASV) in each constructs are less than $0.5(50 \%)$ which reveals satisfactory.

\section{Descriptive and correlation statistics}

As likert scale is used in this study is based upon 5 points; where 1 represents "Not at all" and 5 represents "To Great Extent". The mean Table 3 of LMX and OC constructs is more than 04, and JS is near to 04 which infers that respondents are moderately skewed towards great extent.

The Table 3 also shows that the correlation results among constructs The correlation of Leader Member Exchange with Organizational Commitment is 0.566 (statistically positive) and significant at 0.01 level. 0.6102 positive and significant correlation lies in between LMX \& JS, whereas, JS and OC are positively and significantly correlated having value of 0.6881 . As the three constructs are positively and significantly correlated with one another, hence, the hypothesis $\mathrm{H} 1$ is supported.

The Table 3 also shows that the correlation results among constructs. The correlation of Leader Member Exchange with Organizational Commitment is 0.566 (statistically positive) and significant at 0.01 level. 0.6102 positive and significant correlation lies in between LMX \& JS, whereas, JS and OC are positively and significantly correlated having value of 0.6881 . As the three constructs are positively and significantly correlated with one another, hence, the hypothesis H1 is supported.

Table 2: Overall Reliability of Constructs

\begin{tabular}{llllll}
\hline & & CR & AVE & MSV & ASV \\
\hline LMX & Leader Member Exchange & 0.845 & 0.52 & 0.43 & 0.3 \\
JS & Job Satisfaction & 0.912 & 0.51 & 0.41 & 0.28 \\
OC & Organizational Commitment & 0.883 & 0.5 & 0.31 & 0.21 \\
\hline
\end{tabular}

$\mathrm{CR}$, composite reliability; AVE, average variance shared; MSV, maximum shared variance; $\mathrm{ASV}$, avg. shared variance

Table 3 Correlation

\begin{tabular}{lllll}
\hline $\mathbf{n}=\mathbf{2 2 6}$ & Mean(SD) & $\mathbf{1}$ & $\mathbf{2}$ & $\mathbf{3}$ \\
\hline LMX & $4.1152(0.6810)$ & 100 & & \\
JS & $3.9231(0.7112)$ & $0.6102^{* *}$ & 100 & \\
OC & $3.4346(0.73164)$ & $0.566^{* *}$ & $0.688 I^{* *}$ & 100 \\
\hline
\end{tabular}

Note: LMX, leader member exchange; JS, Job Satisfaction; OC, organizational commitmen

** Significance level: 0.01 Level 


\section{Confirmatory factor analysis}

Confirmatory factor analysis was conducted using AMOS-18 for the validity of measures in this research context by putting all three constructs together The fit indices were used to assess model adequacy, given in Table 4. These fit indices were Root-Mean Square Error of Approximation (RMSEA), CMIN/df, Tucker-Lewis Index (TLI), and Comparative Fit Index (CFI). The threshold for each is the CFI and TLI values above 0.90 and RMSEA scores below 0.08 , but it treated as good fit if its value is below 0.05 that represents a good model fit. Initially model (with all the items for CFA) was tested, the model fit results were not so fit $(\mathrm{RMSEA}=0.08, \mathrm{CFI}=0.89$, TLI $=$ 0.89 , GFI, $0.85 \& \mathrm{CMIN} / \mathrm{df}=2.1$ ). Keeping in view factor loading of 31 items in three constructs, those which found poor loaded were removed. The statistics of model fit were significantly enhanced to an adequate level in the subsequent model that is finalized as shown in Figure 2, the results of fit model are given in Table 5.

Table 4 Measurement model results

\begin{tabular}{llllll}
\hline Model & CMIN/df & TLI & CFI & GFI & RMSEA \\
\hline Model 2 & I.452 & 0.93 & 0.943 & 0.901 & 0.048 \\
\hline
\end{tabular}

Note:TLI, tucker-lewis index; CFI, comparative fit index; RMSEA, root-mean square error of approximation

Table 5 Structural Model Results

\begin{tabular}{lllllll}
\hline Model & Description & CMIN/df & TLI & CFI & GFI & RMSEA \\
\hline Model 2 & Hypothesized Model & 1.548 & 0.916 & 0.928 & 0.901 & 0.052 \\
\hline
\end{tabular}

Note:TLI, tucker-lewis index; CFI, comparative fit index; RMSEA, root-mean square error of approximation

\section{SEM results}

H2 predicted that Leader Member Exchange (LMX) has a significant impact on Job Satisfaction; the hypothesis stated that LMX is related positively to OC. So this was tested using AMOS 18 through SR model as shown in Figure 1 (fit indices shown in Table 6.rt The significant effect was found in between LMX independent variable on JS dependent variable (un-standardized $\beta=.325 ; \mathrm{SE}=.017 ; \mathrm{p}<$ 0.01). Similarly, H3 predicts, Organizational Commitment is related positively to Job Satisfaction, The significant effect was found in between OC and JS (un-standardized $\beta=.455 ; \mathrm{SE}=.124 ; \mathrm{p}<0.01$ ). Hence, $\mathrm{H} 2-\mathrm{H} 3$ both hypotheses were supported.

Hypothesis 04 of this study refers OC mediates the relationship between LMX \& JS. To test this hypothesis, AMOS Graphics was used to check its estimates, Bias Corrected 95\% Confidence interval at 5000 bootstrapping samples (Preacher \& Hayes, 2008). Results of this hypothesis was supported (unstandardized $\beta=.015$; $\mathrm{SE}=.001 ; \mathrm{p}$ $>0.05$ ). Hence, in Table 7, H4, OC acts as mediator between LMX \& JS, was supported (Table 8).

Table 6 Regression Weights

\begin{tabular}{llllll}
\hline & & & Estimate & S.E. & P \\
\hline OC & $<--$ & LMX & 0.325 & 0.117 & 0.005 \\
JS & $<--$ & OC & 0.455 & 0.124 & $* * *$ \\
\hline
\end{tabular}

Table 7 Mediation Analysis Results

\begin{tabular}{llllll}
\hline & & \multicolumn{3}{l}{ Job Satisfaction } & \\
\cline { 2 - 4 } & & BC 95\% Cl & Upper & P \\
\cline { 2 - 4 } & Point of estimate & SE & Lower & & \\
\hline \multicolumn{2}{l}{ Leader Member Exchange } & & & 0.066 & 0.27 \\
\hline Indirect effect & 0.015 & 0.01 & -0.018 & \\
\hline
\end{tabular}

Note: BC, biased corrected (5000 bootstrapping samples)

Table 8 Hypotheses Summary

\begin{tabular}{lll}
\hline & Hypothesis & Results \\
\hline $\mathrm{HI}:$ & LMX, OC \& JS are positively correlated with one another. & Supported \\
$\mathrm{H} 2:$ & LMX is related positively to OC. & Supported \\
$\mathrm{H} 3:$ & OC is related positively to JS. & Supported \\
$\mathrm{H} 4:$ & OC acts as a mediator between LMX \& JS & Supported \\
\hline
\end{tabular}




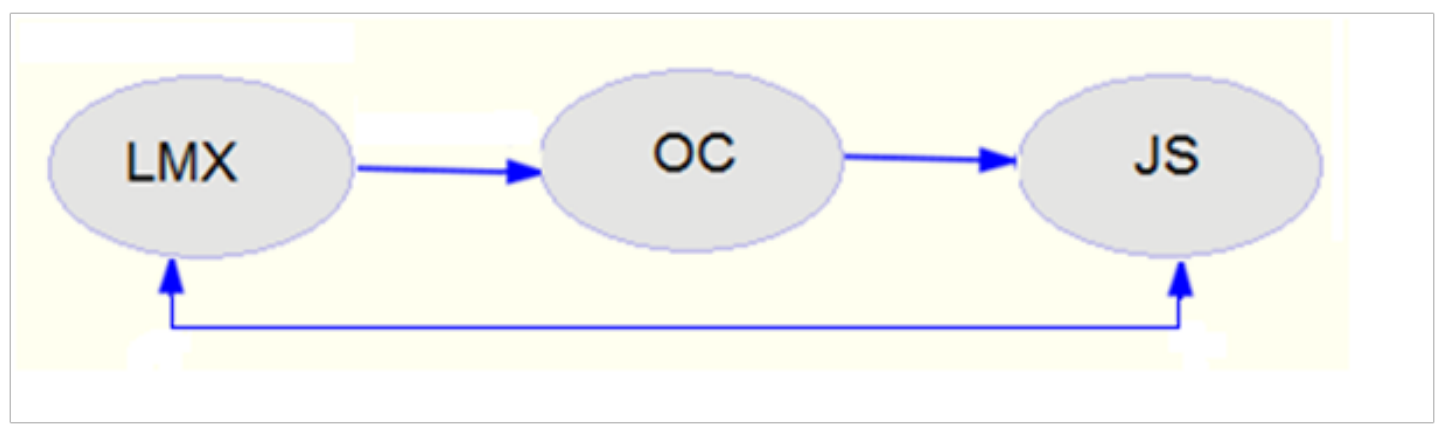

Figure I Hypothesized Model.

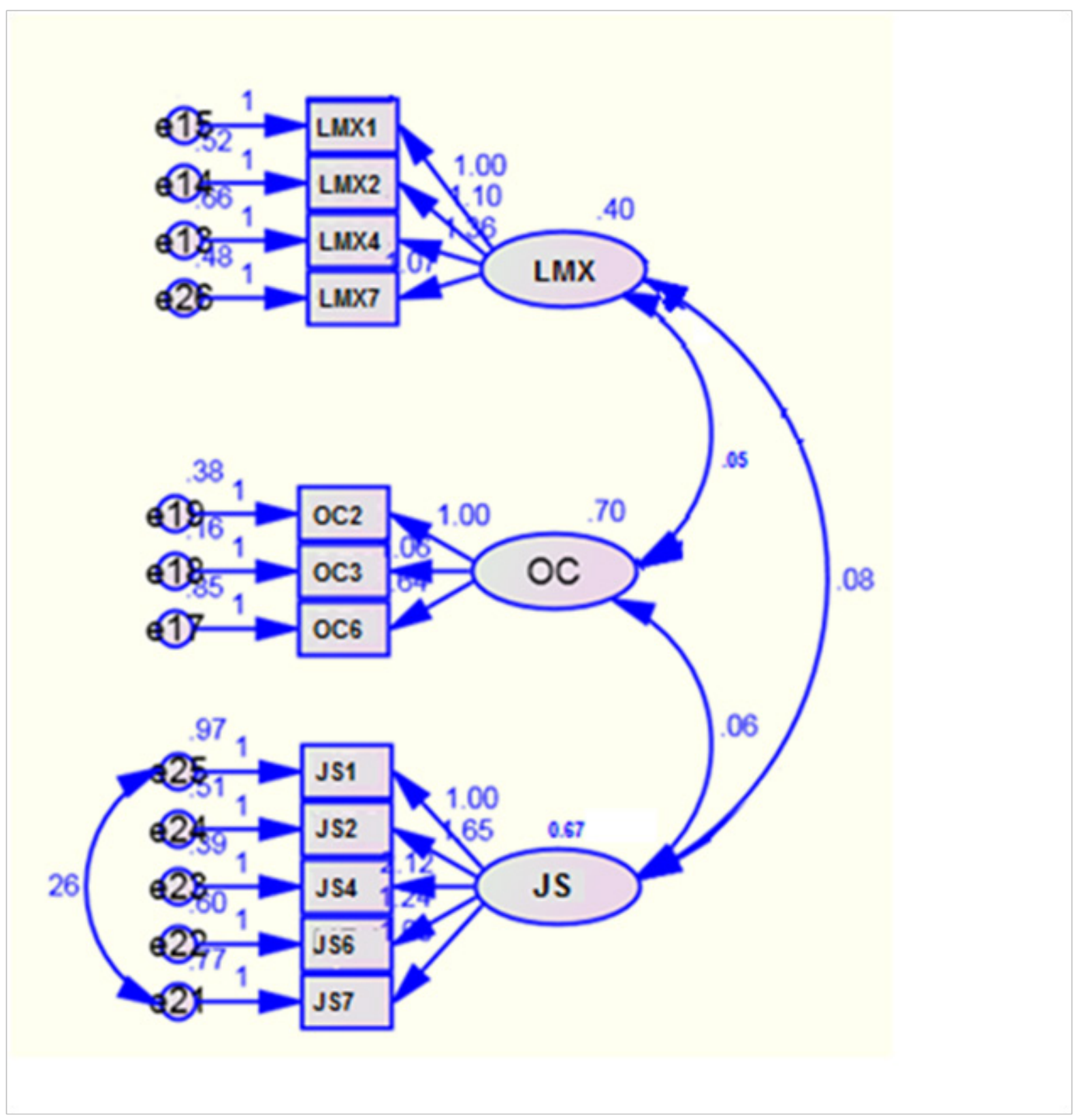

Figure 2 CFA Model. 


\section{Contribution of the study}

Banking is a growing sector of Pakistan; competition has increased to an extent where the human resource retention is very difficult. Therefore this study contributes to the banking sector in the sense that it helps to understand the importance of a good relationship of a leader and follower and its impact on the Job Satisfaction and Organizational Commitment of Employees. This study can be helpful to management in decision making by enabling the better understanding of the human resource relationships.

\section{Conclusion}

It is also belief of finance managers that the profitability of Commercial Banks depends upon organizational performance. In previous three decades, commercial banks have realized great relationship of organizational behavior with profitability. The commercial banks are currently in need of increasing the organizational commitment as according to Ferris ${ }^{45}$ increased rate of LMX is related to OC. The relationship among leader and subordinate is one determinant of organizational commitment towards Job Satisfaction, same goes with the commercial banks in Sindh. From the current study it is presumed that the managers in the commercial banks are not different than others in the world as the respondents responses correspond with the literature. The aim of the study is achieved by completing all the research objectives including the relationship and impact of Leader Member Exchange on Job satisfaction and Organizational Commitment as mediator factor. The results have revealed the same positive and significant impact of LMX on JS as the literature has shown.

\section{Future directions}

To overcome the limitations of the current study, certain future directions are highlighted such as other variables that explain Turnover Intension, Psychological Contract may be taken into account in future research. This study also depict multi-sartorial or cross sectional research to obtain more reliable results. Other moderating as well as mediating variables may be incorporated in the model.

\section{Acknowledgments}

None.

\section{Conflicts of interest}

The authors declare there is no conflict of interest.

\section{Funding}

None.

\section{References}

1. Chee CJ, Chin MY, Wong CW, et al. Impact of macroeconomic variables and bank specific characteristics on commercial bank's performance in Malaysia pre and post crisis period. UTAR Institutional Repository. 2018 .

2. Imam A, Raza A, Ahmed M. Impact of Job Satisfaction on Organizational Commitment in Banking Sector Employees of Pakistan. Science International. 2014;26(1):419-423.

3. Singh A, Singh LB. Determinants of Job Satisfaction and Its Impact on Affective, Continuance, and Normative Commitment of Employees: An Empirical Study. In Multidisciplinary Perspectives on Human Capital and Information Technology Professionals. 2018. pp. 268-289).
4. Islam T. Recruitment and Selection Process of Janata Bank Ltd. Daffodil International University. 2018;1-37.

5. Janssen O. "Job demands, perceptions of effort-reward fairness and innovative work behavior," Journal of Occupational and Organizational Psychology. 2000;73:287-302.

6. Steers RM. Antecedents and outcomes of organizational commitment. Adm Sci Q. 1977;22(1):45-56.

7. Buchanan B II. "Building organizational commitment: The socialization of managers in work organizations". Administrative Science Quarterly. 1974;19(4):533-546.

8. Mowday RT, Steers RM, Porter LW. The measurement of organizational commitment. Journal of Vocational Behavior. 1979;14(2):224-247.

9. Graen GB, Liden RC, Hoel W. "Role of leader-ship in the employee withdrawal process," Journal of Applied Psychology, 1982;67(6):686872 .

10. Graen GB, TA Scandura. "Toward a psychology of dyadic organizing," Organizational Behavior. 1987;9:175-208.

11. Liden RC, Sparrowe RT, Wayne SJ. "Leader-member exchange theory: The past and potential for the future". Research in Personnel and Human Resources Management. 1997;15:47-119.

12. Deluga RJ. "Leader-member exchange quality and effectiveness ratings: The role of subordinate-supervisor conscientiousness similarity". Group and Organization Management. 1998;23(2):189-216.

13. Yukl G. Leadership in organizations ( $5^{\text {th }}$ edn). New Jersey: Prentice Hall. 2001.

14. Dansereau Jr F, Graen G, Haga WJ. A vertical dyad linkage approach to leadership within formal organizations: A longitudinal investigation of the role making process. Organizational behavior and human performance. 1975;13(1):46-78.

15. Dienesch RM, Liden RC. Leader-member exchange model of leadership: A critique and further development. Academy of management review. 1986;11(3):618-634.

16. Gerstner CR, Day DV. Meta-Analytic review of leader-member exchange theory: correlates and construct issues. Journal of applied psychology. 1997;82(6):827.

17. Liden RC, Erdogan B, Wayne SJ, et al. Leader-member exchange, differentiation, and task interdependence: implications for individual and group performance. Journal of organizational behavior. 2006;27(6):723-746.

18. Cogliser CC, Schriesheim CA, Scandura TA, et al. Balance in leader and follower perceptions of leader-member exchange: relationships with performance and work attitudes. The Leadership Quarterly. 2009;20(3):452-465.

19. Graen GB, Uhl-Bien M. Relationship-based approach to leadership: development of leader-member exchange (LMX) theory of leadership over 25 years: Applying a multi-level multi-domain perspective. The leadership quarterly. 1995;6(2):219-247.

20. Wayne SJ, Shore LM, Liden RC. Perceived organizational support and leader-member exchange: a social exchange perspective. Academy of management review. 1997;40:82-111.

21. Van Dyne L, Kamdar D, Joireman J. In-role perceptions buffer the impact of low LMX on helping and enhance the impact of high LMX on voice. Journal of applied psychology. 2008;93(6):1195-1207.

22. Hooper DT, Martin R. Beyond personal leader-member exchange (LMX) quality: The effects of perceived LMX variability on employee reactions. The Leadership Quarterly. 2008;19(1):20-30.

23. Cranny CJ, Smith PC, Stone E. Job satisfaction: how people feel about their jobs. 1992. 
24. Luthans F, Wahl LVK, Steinhaus CS. The importance of social support for employee commitment: a quantitative and qualitative analysis of bank tellers. Organization Development Journal. 1992;10(4):1-10.

25. Kuvaas B, Buch R. Leader-member exchange relationships and follower outcomes: the mediating role of perceiving goals as invariable. Human Resource Management. 2018;57(1):235-248.

26. Fisher CD. Mood and emotions while working: missing pieces of job satisfaction?. Journal of Organizational Behavior. 2000;21(2):185-202.

27. Eagly AH, Chaiken S. The psychology of attitudes. Harcourt Brace Jovanovich College Publishers. 1993.

28. Allen NJ, Meyer JP. The measurement and antecedents of affective, continuance and normative commitment to the organization. Journal of Occupational Psychology. 1990;63(1):1-18.

29. Swailes S. Organizational commitment: a critique of the construct and measures. International journal of management reviews. 2002;4(2):155-178.

30. Okpara JO. Personal characteristics as predictors of job satisfaction: An exploratory study of IT managers in a developing economy. Information Technology \& People. 2004;17(3):327-338.

31. Maxwell G, Steele G. Organisational commitment: a study of managers in hotels". International Journal of Contemporary Hospitality Management. 2003;15(7):362-369.

32. Tella A, Ayeni CO, Popoola SO. Work motivation, job satisfaction, and organisational commitment of library personnel in academic and research libraries in Oyo State, Nigeria. Library philosophy and practice. 2007;9(2):1-17.

33. Shore LM, Tetrick LE. A construct validity study of the survey of perceived organizational support. Journal of applied psychology. 1991;76(5):637-643.

34. Amabile TM. A Model of Creativity and Innovation in Organizations. In: Shaw BM, Cummings LL, editors. Research in Organizational Behavior. 1988;10:123-167.
35. Wiener Y, Vardi Y. Relationships between organizational culture and individual motivation-a conceptual integration. Psychological Reports. 1990;67(1):295-306.

36. Ebikeseye B, Dickson RS. Employee Commitment to Work as an Ingredient for Service Delivery of Selected Firms in Bayelsa State. International Journal of Economics and Business Management. 2018;4(1):80-92.

37. Dienhart JR, Gregoire MB, Downey RG, et al. Service orientation of restaurant employees. International Journal of Hospitality Management. 1992;11(4):331-346.

38. Meyer JP, Paunonen SV, Gellatly IR, et al. Organizational commitment and job performance: It's the nature of the commitment that counts. Journal of Applied Psychology. 1993;74(1):152-156.

39. Needle David. Business in Context: An Introduction to Business and Its Environment. ISBN 978-1861529923. 2004.

40. ChenZ, Lam W, Zhong JA. Leader-member exchange and member performance: a new look at individual-level negative feedback-seeking behavior and team-level empowerment climate. Journal of applied psychology. 2007;92:202-212.

41. Angle HL, Perry JL. Organizational commitment: Individual and organizational Administrative Science Quarterly. 1983;19:533-534.

42. Scandura TA, Graen GB. Moderating effects of initial leader-member exchange status on the effects of a leadership intervention. Journal of applied psychology. 1984;69(3):428-436.

43. Joreskog K.G, Sorborm D. LISREL 7: User's reference guide. 1st ed. Mooreville, IN: Scientific Software. 1989.

44. Browne MW, Cudeck R. Alternative ways of assessing model fit. In KA Bollen, JS Long, editors. Testing structural equation models. Beverly Hills, CA: Sage, 1993. pp. 136-162.

45. Ferris GR. Role of leadership in the employee withdrawal process: A constructive replication. Journal of Applied Psychology. 1985;70(4):777. 